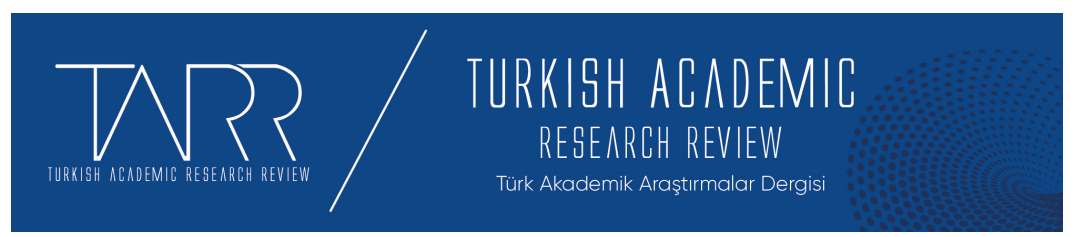

e-ISSN: 2602-2923 Yil/Year: $2021 \quad$ Cilt/Volume: 6 Sayı/Issue: 1 Halit Ziya'nın Aşk-ı Memnu Romanında Kadın Temsillerinin
Toplumsal Cinsiyet Açısından İncelenmesi

Examınatıon of Female Representatıons in Halit Ziya's Novel Așk-1 Memnu in Terms of Gender

\title{
Erdi DEMIR
}

Doktorant, Akdeniz Uygarlıkları Araştırma Ens. Yeni ve Yakınçă̆ Araştırmaları ABD, edemir.akdeniz@gmail.com, Orcid ID: 0000-0003-3227-5984

\begin{tabular}{r|l} 
Makale Bilgisi & Article Information \\
Makale Türü - Article Type & Araştırma Makalesi / Research Article \\
Geliş Tarihi - Date Received & 01 Şubat / February 2021 \\
Kabul Tarihi - Date Accepted & 22 Mart / March 2021 \\
Yayın Tarihi - Date Published & 25 Mart / March 2021 \\
Yayın Sezonu & Ocak - Şubat - Mart \\
Pub Date Season & January - February - March
\end{tabular}

Atıf / Cite as: Demir, Erdi, Halit Ziya'nın Aşk-1 Memnu Romanında Kadın Temsillerinin Toplumsal Cinsiyet Açısından İncelenmesi/Examınatıon of Female Representations in Halit Ziya's Novel Aşk-1 Memnu in Terms of Gender. tarr: Turkish Academic Research Review, 6 (1), 293-307. doi: 10.30622 tarr.872711

Intihal / Plagiarism: Bu makale, en az iki hakem tarafından incelenmiş ve intihal içermediği teyit edilmiştir. / This article has been reviewed by at least two referees and confirmed to include no plagiarism. https://dergipark.org.tr/tr/pub/tarr

Copyright (C) Published by Mehmet ŞAHIN Since 2016- Akdeniz University, Faculty of Theology, Antalya, 07058 Turkey. All rights reserved.

Turkish Academic Research Review - Türk Akademik Araştırmalar Dergisi 


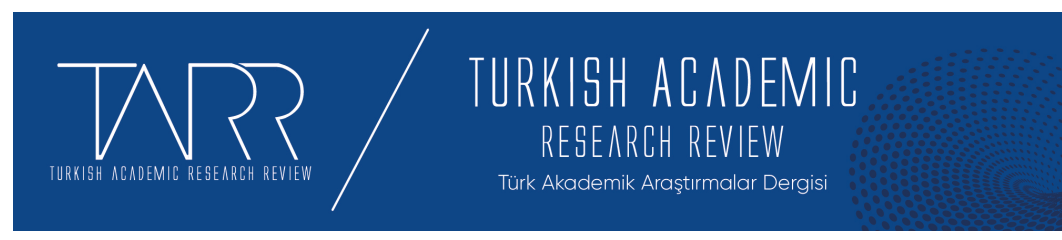

e-ISSN: 2602-2923 Yil/Year: $2021 \quad$ Cilt/Volume: 6 Sayı/Issue: 1

\section{Halit Ziya'nın Aşk-ı Memnu Romanında Kadın Temsillerinin Toplumsal Cinsiyet Açısından İncelenmesi}

\section{Erdi DEMIR}

Özet

$\mathrm{Bu}$ çalışma, toplumsal cinsiyet normlarının edebi bir metindeki yansımalarını konu almaktadır. Eser, kaleme alındığı dönemin fikir geleneği, yaşam pratikleri ve kadına karşı bakış açısını yansıtması bakımından önem arz etmekle beraber kadın çalışmaları ve toplumsal cinsiyet disiplini açısından zengin bir veri kaynağı sunmaktadır. Çalışmada, kadın kimliği konusuyla ilgili literatür taraması yapılarak toplanan verilerin doküman incelemesi yapılmıştır. Çalışmada yapıta bağlı kalmak üzere kadın karakterler üzerinden toplumsal roller ve eylem biçimlerinin toplumsal cinsiyet normlarıyla olan ilişkisi incelenmiştir. Çok eşlilik, yasak aşk, aldatma gibi konuların, toplumsal değer çatışmalarının kadın karakterler üzerinden sunumunun yapıldığı anlaşılmış, yapıtın ataerkil bir bakış açısıyla kurgulandığı soncuna ulaşılmıştır. Yapıtta, toplumsal cinsiyet rolleriyle uyumlu (itaatkâr, fedakâr, uysal, sessiz) kadınlar ideal ve ahlaki olgunluğa sahip kimseler olarak kurgulanırken özgürlükçü ve bağımsız kadın tiplerinin olumsuz eleştirisinin yapıldığı tespit edilmiştir. Halid Ziya Uşaklıgil'in eseri Aşk-ı Memnu, kadınların toplumsal statü ve konumlarının toplumsal cinsiyet bakış açısıyla değerlendirilebilmesi için zengin bir veri kaynağı sunmaktadır. Aşk-ı Memnu'da yasak aşk konusu üzerine şekillenen mutsuz bir evlilik ve bu evliliğe yol açan sebepler ve sonuçları anlatılmaktadır. Yapıtta Batılılaşmayı, giyim, kuşam ve modadan ibaret gören, Fransızca öğrenmek, piyano çalmak ile modernleştiğini sanan insanların özgürlük aracıllğııla Türk aile yapısına uygun düşmeyen yaşam biçimleriyle (gece partileri, gezintiler, flörtler ve yasak aşklar, kaçamak ilişkiler, aldatmalar, kamusal alanda erkek-kadın görünümleri) toplumsal ve kültürel değerleri kaybedişi anlatılmaktadır.

Anahtar Kelimeler: Aşk-ı Memnu, Yasak aşk, Toplumsal cinsiyet, Ataerkillik, Kadın

Turkish Academic Research Review - Türk Akademik Araştırmalar Dergisi 


\title{
Examınatıon of Female Representatıons ın Halit Ziya's Novel Aşsk-ı Memnu in Terms of Gender
}

\begin{abstract}
This study focuses on the reflections of gender norms in a text. The work provides a rich source of data from women's studies and gender discipline, which is important in that it reflects the idea of the period in which it was written, life practices and perspective towards women. The study conducted a weaver review of data collected by reviewing literature on the topic of female identity. In the study, the relationship of social roles and forms of action on female characters with gender norms was examined. It was understood that issues such as polygamy, forbidden love, and deception were presented on the female characters of social value conflicts, and it was finally achieved that they were established from a patriarchal point of view. It has been found that while women who are compatible with gender roles (obedient, altruistic, docile, silent) are fictionalized as those who have ideal and moral maturity, negative criticism of libertarian and Independent Women types is made. Khalid Ziya Uşaklıgil's works Aşk-1 satisfied provide a rich data source for evaluating the social status and positions of women from a gender perspective. Aşk-1 Memnah describes a marriage of unhappy people formed on the topic of forbidden love and the reasons and consequences that lead to this marriage. Which Westernization, who's clothing and fashion learn French, play the piano, although a rapid with the freedom of the people who thinks through the Turkish family structure does not fit into a way of life (with all-night parties, rides, flirtations, and forbidden love, extra-marital relationships, deception in the public sphere, the malefemale views) describes a loss of social and cultural values.
\end{abstract}

Keywords: Aşk-1 Memnu, Forbidden love, Gender, Patriarchy, Woman

\section{Structured Abstract}

This study focuses on the reflections of gender norms in a text. The work provides a rich source of data from women's studies and gender discipline, which is important in that it reflects the idea of the period in which it was written, life practices and perspective towards women. The study conducted a weaver review of data collected by reviewing literature on the topic of female identity. In the study, the relationship of social roles and forms of action on female characters with gender norms was examined. It was understood that issues such as polygamy, forbidden love, and 
deception were presented on the female characters of social value conflicts, and it was finally achieved that they were established from a patriarchal point of view. It has been found that while women who are compatible with gender roles (obedient, altruistic, docile, silent) are fictionalized as those who have ideal and moral maturity, negative criticism of libertarian and Independent Women types is made. Khalid Ziya Uşaklıgil's works Aşk-1 satisfied provide a rich data source for evaluating the social status and positions of women from a gender perspective. Aşk-1 Memnah describes a marriage of unhappy people formed on the topic of forbidden love and the reasons and consequences that lead to this marriage. Which Westernization, who's clothing and fashion learn French, play the piano, although a rapid with the freedom of the people who thinks through the Turkish family structure does not fit into a way of life (with all-night parties, rides, flirtations, and forbidden love, extra-marital relationships, deception in the public sphere, the malefemale views) describes a loss of social and cultural values. In Aşk-1 Memn, there are two types of women who cover the literature of the Tanzimat and Servet-1 Fünun period. First, a chaste, docile type of woman who tries to hide her sexual identity, even if she is a chambermaid, concubine, slave, is a scheming, lewd type of woman who knows happiness other than the pleasure of the other ISE and skin. What is interesting is that forms of behavior and Social Action, called chastity, cheekiness and immorality, are considered modern or contemporary symbols. The definition of women in the household as pure, clean, chaste, altruistic and ideal women who obey men, the demotion of women in the public sphere, the depraved, lewd qualities are quite striking. The phenomenon of women's identity entered Turkish social life after the Tanzimat edict within the framework of rights, freedoms, the social status and position of women. A number of social rights were granted to women by the Tanzimat edict, educational institutions for girls and women, nursing schools were opened. In fact, the Tanzimat edict covers military and legal reforms due to military defeats against the West. II. During the constitutional period, developments in women's rights and freedoms continued, numerous women's associations were established, and women's magazines were published. Women began to practice professions such as teaching, nursing, and Midwifery. Sultan II. Given that during the reign of Abdulhamid (1876-1909), women were forbidden to travel in the public sphere in thin cloth dresses, it is better to understand how much the women's movement had gained in Ottoman society. II. During the constitutional period, the institutions of Union and Progress Administration were initially given great support for the strength of the women's movement. The reason why the women's movement gained momentum during this period; the women's movement can be supported by

Turkish Academic Research Review - Türk Akademik Araştırmalar Dergisi 
both Young Turks and non-governmental associations, and the publication of women's magazines can be shown more accurately the institutionalization of the women's movement. Female characters such as Firdevs Hanım, Mademoiselle, Nihal, Bihter, Peyker, Şayeste Hanım and Cemile in the work are generally characterized as opposite to each other and opposite to each other. Established as a cheating, scheming, lewd woman, Firdevs Hanım and her daughter Bihter's lives are exaggerated in individual and psychological roofs, while emphasis is placed on massage, pure, fun and positive aspects of male characters compared to female characters. Behlil's polygamy, philandering, mischief and irresponsible behavior are not negatively reflected, while the conflicts of Honor, morality and social value are presented on female characters. Although the work mentions a YALI who lived a Western-type life and the individual lives of its inhabitants, the existence of a society governed by the rules of religion is mentioned. This situation determined the direction and form of public-private space, space and social relations. Behlul is a polygamous man who is patriarchal, inclined to status and power, although he is presented as a Western allusion to image, clothing, social practices, thought, way of life and culturally. The behavior of women such as Mademoiselle, who shows the feelings of chaste, demure, compassion, love, is presented correctly and ideally, while the sequential freedom of Bihter, who has the right to choose marriage or even argue with her mother about it, is criticized. She is a female representative, quiet, obedient, altruistic, and in all respects male, compatible with the collective gender rollers. Women who do not wake up with gender roles, women who are unhappy by observing material interests, who lose their wives, whose material and spirituality cannot achieve pleasure, whose ends do not become good, reveal that the work is written from a male-dominated point of view. The fact that the elements of power and power are gathered in the male characters, the status and dignity of a woman can be determined by men, can be considered a projection of this patriarchal approach. It is possible for women to have dignity and state in the hands of obedience to a maledominated social order. Bihter's suicide as a result of the appearance of forbidden love can be read as an attempt to clean up the honor of her husband Adnan Bey, not an attempt to protect her own identity. As a matter of fact, it seems that the way to keep women under control is social control mechanisms such as morality, honor, chastity. 


\section{Toplumsal Cinsiyet ve Kadınlık}

Toplumsal cinsiyet, toplumun kadın erkek ilişkilerine bakış açısını yansıtan, toplumsal değerler, gelenekler ve görenekler üzerine inşa edilen normlardır. Toplumun uzun yıllardır sahip olduğu düşünce stili ve fikir geleneğini yansıtan bu normlar, ataerkil, cinsiyetçi bir yaklaşımın ürünüdür. Toplumsal cinsiyetin izdüşümlerine edebiyatta, sanatta, sporda, ekonomide, siyasette, kamusal alanda ve birçok toplumsal kurumda rastlamak mümkündür.

Toplumsal cinsiyet normları, biyolojik cinsiyet üzerine yüklenen kültürel ve sosyolojik pratikleri işaret etmektedir(Demir, 2020: 833). Toplumsal Cinsiyet, erkek ile kadın arasındaki güç ilişkilerini anlayabilmek, toplumsal yaşamda olup bitenleri algılamak ve eşitsizlikleri vurgulamak için kullanılan bir kavramdır (Ecevit, 2011: 4,5; Karkıner, 2011: 149). Kadınlardan ve erkeklerden beklenen toplumsal davranış ve eylemler toplumsal kabul ile yakından ilgilidir. Berktay'a (2000) göre; tarihsel ve kültürel çalışmalar kadın-erkek sosyal ilişkisinin temeline 1 şı tutmaktadır. İlk çağlardan günümüze iş bölümü ve uzmanlaşma kavramları, özel mülkiyetin gelişmesi günümüze kadar kadın-erkek ilişkilerinin biçimlenmesinde önemli rol oynamıştır. Kadınlara ya da erkeklere toplum tarafından biçilen kültürel motifler, kadınlara duygusal olma, yardımsever ve şefkatli olma, uzlaşmacı ve yapıcı tavırlarla sosyal ilişkiler kurma gibi bir dizi toplumsal bilinçaltı unsurları öğretmektedir (Ecevit, 2011: 4). Erkekler, toplumsal cinsiyet normlarına göre, rasyonel olma, para kazanma, risk alma, rekabet ve mücadeleci olma, kararlı ve güçlü olma, duygusallıktan öte menfaatleri gözetme, koruyucu ve gözetici olma gibi değerlerle özdeşleşmiştir (Atay, 2004: 11; Sancar, 2011: 169,170). Bu durum cinsiyet farklılıklarına dayalı bir toplumsal rejimin şekillenmesine sebep olmuştur. Örneğin kadınlar kamusal alanda estetik giyindikleri vakit cinsellik objesi olarak algılanmaktadırlar. Gögüs çatalı görünen bir bayanın durumu "dekolte”; mini etek giydiği vakit iç çamaşırı görünen kadın ise "frikik" vermiş sayılırken, iç çamaşırı ya da fermuarı açık kalmış bir erkeğin durumu ise "frikik" olarak adlandırılmamaktasıradan bir unutkanlık olarak yansıtılmaktadır (Elçik, 2011: 148). Ayrıca eşinden boşanmak isteyen kadına toplum nazarında iyi gözle bakılmaması, eşinden boşanması sonrası gayri ahlaki kötü yollara sevk olacağına inanılması toplumsal cinsiyetçi bakışın birer yansıması kabul edilebilir. Araç pazarlama ve satışlarında bikinili, iç çamaşırlı ve yüksek topuklu kadınların araçların önünde poz vermesi,satılık, hiç kullanılmamış, sıfır kilometre araçlar için "kız gibi araç" ifadelerinin kullanılması kadınların bekâretine vurgu yapan cinsiyetçi hegemonik norm ve söylemlerden sadece bir kaçıdır. Kısaca ataerkil bakış açısının pekişmesi

Turkish Academic Research Review - Türk Akademik Araştırmalar Dergisi https://dergipark.org.tr/tr/pub/tarr 
olarak kadınlık ve erkeklik adı verilen normlartoplumsal hayatı ve sosyal ilişkileri kadınlar aleyhine değiştirip dönüştürmektedir. Kadınlar, sosyal bir varlık olarak toplumsal hayatta ve kamusal alanda dışlanmakta, erkeklerle eşit hak ve özgürlüklere sahip olamamaktadır. Toplumsal cinsiyet perspektifinde kadınlık imgesi, hane içi konumlu, temizlik, yemek ve çocuk bakımı gibi karşı1ıksız emekle özdeşleşmiştir. Bu durum kamusal alanda karşllkklı emekle geçimini temin eden erkeklerin kadınlar karşısında konumunu güçlendirmekle beraber, her iki cins arasında hiyerarşiye dayanan sosyal ilişkiler ağını inşa etmektedir (Ecevit, 2011: 27; Demir, 2018:15).Kadınlık ve erkeklik fiziksel özellikleri vurgulamak bir yana sosyal yapı tarafından belirlenen toplumsal roller ve eylem biçimlerini öne çıkarmaktadır. Sosyal bileşenler, kadınlık ve erkeklik yapılarını biçimlendirmekte ve işlevlik kazandırmaktadır. Medya, spor kültürü, sünnet törenleri, askere gitmek, evlenmek, dövüşmek önemli erkeklik testleri olarak algılanmaktadır (Connel, 2001).

\section{Tanzimat Dönemi ve Kadın Konusu}

Tanzimat dönemi roman ve edebi metinlerde kadın konusu,kadının eğitimi, aşk, yasak aşk, görücü usulü evlilik, aldatan kadın, cariyelik, kölelik, çok eşlilik, namus, iffet gibi konular etrafında ele alınmaktadır. Edebi eserlerde, dönemin sosyal ve kültürel değerleri, gelenekleri ve ahlak kurallarına bağlılık gibi kültürel motiflerini görebilmek mümkündür. Nitekim kaleme alınan eserlerin büyük bir çoğunluğunda yıkılmaya yüz tutmuş bir devlet ile Batılılaşma arasında tutum ve değerler çatışması yaşayan toplumsal karakterler görülmektedir (Çetin, 2002; Karabulut, 2013: 66).

Kadın gündeme geldiğinde mekân kurgulama bakımından sınırlılık getiren, kamusal alan ile özel alan arasında ikilem yaşayan yazarlar, toplumsal değerleri, yaşam biçimlerini ve sosyal yapıyı göz önünde bulundurmak suretiyle kadınları genellikle hane içinde cariye, ikinci eş, zorla evlendirilen kadın gibi pasif ve edilgen toplumsal rollerle temsil etmişlerdir (Gökçek, 2000; Günay Erkol, 2011: 149). Nitekim din kurallarıyla yönetilen bir toplumda kamusal alanda bir kadının özgürce bir erkek ile el ele tutuşarak yürümesi yasaktır ve doğal olarak kadınlar sosyal ilişkilerini hane içerisindeki konumlarına göre şekillendirmektedir. $\mathrm{Bu}$ durum ise kadınların erkeklerle mektup yoluyla iletişim kurabilmesine görücü usulü evliliklerin pekişmesi, aile baskısı sonucu evlilikler gibi durumlara sebep olabilmektedir (Tekin, 2010: 85).Dolayısıyla Tanzimat dönemi eserlerinde erkeklere sosyal ve ekonomik yönden bağımlı, itaatkâr ve iffetli, erkeklerin çok eşliliğine ses çıkaramayan, çocuk doğurarak soyun devamını sağlayan kadın profilleri çizilmiştir (Kandiyoti, 1997; Gülendam, 2006).Eserlerde çoğunlukla romantizmin etkisiyle batıya öykünen, 
Boğaziçi'nde yalılarda lüks ve müreffeh bir hayat süren, sandal gezintilerine çıkan, piyano çalmayı öğrenen, Fransızca konuşabilen kadın tiplerine yer verilirken diğer taraftan itaatkâr ve toplumsal statüsü hane içi rolleri ile doğru orantıll olan, fedakâr, eşine bağlı aynı zamanda ideal anne kadın tiplerine yer verilmektedir. Romantizmin ve Fransız edebiyatının etkisiyle iyi ve kötü kadın, ahlaki yozlamış kadın ile iffetli kadın ikilemi sıkça kullanılan motifler arasındadır (Namlı, 2019: 210).Ataerkil bir bakış açısının ürünü olan cariyelik, kölelik, odalık, halayıklık gibi kadın temsillerine sık sık yer verilmesi toplumsal bakış açısının ve yaşam pratiklerinin birer yansıma olarak değerlendirilmektedir. Ahmet Mithat Efendi'nin Felatun Bey ile Rakım Efendi isimli eserinde parayla satın alınan bir köle olan "Canan" tipi ön plana çıkmaktadır. Canan ${ }^{1}$, köle olmasına rağmen, diksiyon, konuşma, dil eğitimi almış ideal bir kadın olarak sunulmaktadır. Sami Paşazade Sezai’nin Sergüzeşt isimli eserinde "Dilber" isimli kadın karakter para ile satın alınan bir cariyedir ve Namık Kemal'in İntibah isimli eserindeki "Dilaşup" adındaki kadın karakter için de aynı durum geçerlidir. Tüm bu kadın karakterlerin ideal bir kadın şeklinde tanıtılmasının ortak tarafi; erkek egemenliğini kabul eden ve itaatkâr kadın olmalarıyla ilgilidir (Moran, 1999: 253).

Tanzimat ve sonrasında verilen eserler teknik ve kurgu açısından zayıf olsa da dil, üslup ve içerik yönüyle batılı anlamda gerçekçi eserler de kaleme alınmıştır (Tanpınar, 2001). Bu gerçekçi eserlerden birisi;olay örgüsü ve karakterleri gerçek olan, realist ve psikolojik özellikler taşıyan, Halit Ziya Uşaklıgil'in Aşk-ı Memnu isimli romanıdır (Kantemir, 1982: 228). Aşk-1 memnu, olayların gelişim evrelerini kadınlar üzerinden kurgulayan, örtünme, evlilik tercihinde özgür kadın temsillerinin sunulduğu, batılı anlamda modern bir romandır (Tanpınar, 2001). Eserin konusu, yaşam biçimini benimsemiş bir Türk ailesi sunulmakla birlikteeğlence düşkünü, gezmek ve eğlenmekten başka sorunları olmayan bir kadının, duygularıyla değil maddi menfaatler gözeterek zengin bir adamla evliliği ve bu evlilik içinde başka birisi ile yasak aşkını konu almaktadır (Çetin, 2002: 20).

\section{Aşk-ı Memnu}

Adnan Bey, İstanbul'da Boğaziçi’nde Nihal ve Bülend isimli çocukları ile varsıl bir yaşam süren, zengin, dul 46-50 yaşlarında bir adamdır. Eşini, ikinci çocuğu Bülend dünyaya geldiğinde kaybeden Adnan Bey, Melih Takımı olarak bilinen Firdevs

${ }^{1}$ Canan, Ahmet Mithat Efendi'nin Felatun Bey ili Rakım Efendi isimli yapıtında Rakım Efendi tarafından esirciden 100 altına satın alınan Çerkez bir cariyedir. Toplumsal cinsiyet normlarıyla uyumlu tutum ve davranışlarıyla ön plana çıkan, bir tiptir.

Turkish Academic Research Review - Türk Akademik Araştırmalar Dergisi https://dergipark.org.tr/tr/pub/tarr 
Hanım'ın küçük kızı Bihter ile evlenmeyi arzu etmektedir. Firdevs Hanım 45 yaşlarında, başkalarının aşk tekliflerine cevap vermiş, eşini başka erkeklerle aldatmış, bakımlı, güzel ve yaş takıntısı olan bir kadındır. Kızları Peyker ve Bihter yüzünden yıpranıp yaşlandığı gerekçesiyle kızlarına içten içe kin besleyen Firdevs Hanım, Adnan Beyin kendisine evlilik teklif etmesini beklerken, kızı Bihter ile Adnan Bey'in evlenmesi karşısında hayal kırıklığına uğramaktadır.

Bihter, eğlenmekten, giyinmekten, mesire alanlarına ve sandal gezintilerinden çok hoşlanan bir kadındır. Bihter, lüks yaşamayı ve tüketmeyi seven bir tiptir.Adnan Bey ile evlenerek annesinden kurtulmayı ve Adnan Beyin yalısına taşınarak zengin bir hayat yaşamayı planlamaktadır. Bu amaçla Adnan Bey ile aralarındaki yaş farkına rağmen bu evliliği kabul eder. Adnan Bey’le evlenen Bihter, bir süre sonra aralarındaki yaş farkından dolayı uyumsuz bir evlilik yaptığını, Adnan Bey'in duygu, heyecan ve ihtiyaçlarına cevap veremediğini fark eder. Bihter, Adnan Beyin genç ve yakışıklı yeğeni Behlül'e gönlünü kaptırır ve aynı evin içerisinde yasak aşk yaşamaya başlar.Behlül ise, amcasının mal varlığı sayesinde tıpkı onlar gibi zengin bir hayat yaşayan, çok eşli, çapkın, sorumsuz bir gençtir. Babasını Bihter'e kaptıran Nihal, Bülend'in yatılı okula gönderilmesi ve bazı hizmetlilerin (Şakire Hanım, kocası Süleyman Bey ve Kızları Cemile) evden gönderilmesinden Bihter’i sorumlu tutmaktadır ve yalıda gittikçe yalnızlaşmaktadır.Kendi konağındaki rutubeti bahane eden Firdevs Hanım, tıpkı kızı Bihter gibi Adnan Beyin sahip olduğu varsıl hayatın nimetlerinden faydalanabilmek için kızının yalısına taşınır ve kısa sürede kızıyla Behlül arasında bir ilişki olduğunu sezer. Bir annelik içgüdüsüyle kızının evliliğini korumak, maddi ve manevi menfaatlerini kaybetmemek için evin kızı Nihal ile Behlül 'ün aralarını yapmaya çalışır ve bu konuda da başarılı olur. Hâlbuki kardeş gibi büyüyen Behlül ile Nihal'in yakınlaşması Matmazel De Courton'u rahatsız etmektedir. Matmazel, bir mürebbiye olarak 3-4 yaşlarından beri bir anne şefkati ve merhameti ile Nihal'e sahip çıkan, temiz yürekli, iyiliksever bir kadındır. Behlül'den uzak durması aksi halde büyük acılar çekeceği yönünde Nihal'i uyarmışsa da fayda etmemiş, Nihal gönlünü Behlül'e kaptırmıştır. Bütün bu gelişmeler içinde evin hizmetlisi, bahçıvanı Beşir, saf bir kalple Nihal'e âşıktır.

Beşir tüm olan bitenleri dışardan gözlemleyerek, Nihal'in zarar görmemesi için bir süre susar ve sonrasında harekete geçer. Nihal'in Behlül ile yakınlaşması Beşir'i çıldırtır ama karşılıksız aşk, O’nu üzüntüsünden hasta eder. Bir gün Bihter'in Behlül 'ün odasından çıktığını ve uzun zamandır seviştiklerini Adnan Beye anlatması üzerine Adnan Bey çılgına döner ve hesap sormak için Bihter'in yanına gittiğinde durumdan haberdar olan Bihter, Adnan beyin onuru, kendi yaşadığı psikolojik 
incinme, yasak ilişkinin verdiği pişmanlıkla intihar ederek hayatına son verir. Büyük bir travma yaşayan aile, evden gönderilen Şayeste Hanım ve ailesini, Fransız Matmazel'i geri çağırır, Bülend yatılı okuldan geri alınır. Sonunda büyük üzüntülerin ardından tekrar huzurlu ve mutlu bir hayat sürmeye başlarlar.

\section{Toplumsal Değerler Çatışması Yaşayan Kadınlar: Firdevs Hanım-Bihter}

Aşk-1 Memnu' da Türk toplumunun alışık olmadığı Batılı yaşam tarzıyla ön plana çıkan giyim kültürü, tüketmek ve eğlenmek için yaşayan Firdevs Hanım, olumsuz özellikleri ile kurgulanmıştır. Firdevs Hanımın eşi dışında başka erkeklerle görüşmek ve mektuplaşmak şeklinde yaşam biçimi eleştirilmekle berabergelenekçi, muhafazakâr aile yapısı ile uyumsuzluk konusunun kadın karakter üzerinden sunulduğu görülmektedir. Firdevs Hanımın başka erkeklerle mektuplarını okuyan eşi, üzüntüsünden hastalanıp ölmüştür. Eserde aile sadakatsizliği, ahlaki yozlaşmanın temsili Firdevs Hanım tarafından paylaşılmış, diğer taraftan özgürlükçü kadın imgesinin olumsuz eleştirisi yapılmıştır. Çünkü özgürlüğün ve ahlaki sinırlılıkların olması, Türk aile yapısına uygun değildir zira ailevi trajedilere yol açabilecektir (Maden, 2008: 80; Şahin, 2010: 122).

Aile birliğinin korunmaması, sadakatsizlik, yasak aşk ile özdeşleşen diğer karakter Firdevs Hanımın kızı Bihter'dir. Geleneksel toplumsal değer ve normlar ile batılı ve özgürlükçü yaşam biçimi arasındaki çatışmayı temsil eden Bihter karakteri, Adnan Bey ile evli olmasına rağmen gençlik, heyecan ve şehvet duygularına hâkim olamayan bir kadın tipi olarak sunulmaktadır (Kantemir, 1982: 237). Adnan Bey ile yaşça uyumsuzlukları, maddi çıkarlar gözeterek yapılan evliliği bahane ederek Adnan Bey'in yeğeni Behlül ile yasak aşkı yansıtılmaktadır. Bihter'in toplumsal cinsiyet rolleri ile uyumsuz bir biçimde, itaatkâr, fedakâr, sadık bir eş olmaması eleştirilirken Behlül 'ün çok eşliliği, çapkınlığı ve sorumsuzluğu problem olarak görülmez. Nitekim Halit Ziya, yapıtında çevredeki kadınları merkeze taşımış, olay örgüsünü kadın karakterler üzerine inşa etmiştir.

\section{Özgürlükçü Kadın-Muhafazakâr Kadın İmgesi: Bihter, Peyker ve Nihal}

Bihter, Adnan Beyin kendisiyle evlenmek arzusu karşısında eserin kaleme alındığı dönemde olağan olmayan bir biçimde evlilik konusunda seçme ve söz hakkına sahip olan, bağımsız, özgürlüğünü savunan bir kadın olarak annesi ile münakaşa etmiştir. $\mathrm{Bu}$ durum, ataerkil ve din kuralları ile yönetilen bir toplumda alışık olunmayan bir ilgi uyandırmıştır (Günay Erkol, 2011: 160). Bihter'e karşılık Nihal ise hayatında gördüğü ve tanıdığı ilk erkek olan Behlül ile evlenmek istemiş, narin, kırılgan,

Turkish Academic Research Review - Türk Akademik Araştırmalar Dergisi 
duygusal ve feminen tutumlarıyla ön plana çıkmıştır (Moran, 1999).Nihal, zengin ve iyi bir eğitim almış ailenin mensubu olmasına rağmen şımarmaktan imtina eden, kibar ve ahlaki olgunluğa sahip bir kadındır. Davranış ve eylemleri ölçülü, uysal genç bir kadın olan Nihal, kültürel muhafazakârlığın iyi niyet ve temiz aşkın sembolüdür (Kantemir, 1982: 238; Çetişli, 2004).

Aynı şekilde Bihter'in ablası Peyker, Behlül 'ün ahlaksızca aşk tekliflerine olumsuz cevap vererek, ailesini ve eşi Nihat’’ koruyucu, kollayıcı tavırlarıyla kız kardeşinin zit karakteri olarak konumlanmıştır. Dikkate değer husus, yazarın olumsuz, kötü ve hoş olmayan durum ve konuları ataerkil düşüncenin etkisiyle kadın karakterler üzerinden sunması olmuştur.

\section{Aldatan Kadınlar: Firdevs Hanım, Bihter}

Firdevs Hanım ise eşi Melih Beyi başka erkeklerle aldatan, ahlaki değerler noktasında nasibini almamış birisidir. Eşinin başka erkeklerle mektuplarını okuyan Melih Bey üzüntüsünden ölmüştür. Meşrep, sadakatsiz ve aldatan bir kadın olan Firdevs Hanım, hayatı boyunca lüks, zengin ve müreffeh bir hayat sürme arzusu ile hareket etmiş, menfi özellikleri ile hem hane içinde hem de hane dışında boy göstermiş entrikacı bir kadındır. Bu sebeple adı çıkmış ve kendisinden kötü sözle bahsedilen bir üne kavuşmuştur (Öztürk, 1998: 128; Nisan \& Bekiroğlu, 2016: 55). Erkekleri, kendi kızlarından daha fazla benimseyen Firdevs Hanım yaşının gerektirdiği ahlaki olgunluğa sahip olamayan, annelik statüsünden çok meşrepliği ile öne çıkan bir kadındır. Bu sebeple Aldatan kadın temsilinin öncülüğünü yapmaktadır.

Firdevs hanımın küçük kızı Bihter, Adnan Bey ile evliliğine rağmen aynı yalıda yaşadıkları Adnan Beyin yeğeni Behlül ile yasak aşk yaşayan, aldatan, sadakatsiz ve annesi gibi ahlaken yozlaşmış bir kadındır. Evliliği öncesinde bakımlı, giyinmeye düşkün ve eğlenceli bir hayatı olan Bihter, evlendikten sonra Adnan Bey ile aralarındaki yaş farkını bahane ederek şehvet ve heyecan duygularına mağlup olmuş, iradesine hâkim olamamıştır (Zariç, 2017: 154). Bihter, annesinin huy ve mizaçlarını taşıyan, yetinmekten ziyade tüketmek için yaşayan ve ihanet eden bir kadını temsil etmektedir. Bihter, uyumsuz ve çiftler arasında yaş farklılı̆̆ fazla evliliklerin sorun olacağını, aynı zamanda para ve maddi menfaatler gözetilerek yapılacak bir evliliğin ise saadet getirmeyeceğinin temsili niteliğindedir (Öztürk, 1998: 129). Bihter'in, annesinden aldığı kişiliği, ten uyumunun dışında bir haz ve sevgi anlayışının olmaması, Adnan Beyin onun ruhuna ve heyecanına karşılık verememesi, Behlül 'ün cezbediciliği ve çapkınlığı yasak ilişkiye sebep olmuştur (Çetin, 2002: 31). 


\section{İfetli Kadınlar: Matmazel De Courton, Nihal}

Fransa'dan İstanbul'a gelen ve bir Rum ailesinin yanında bir süre mürebbiyelik yaptıktan sonra Adnan Beyin yalısında Nihal'e bakıcılık yapan Matmazel, evlenmemiş bir kadın olmamakla birlikte ağırbaşlı, iffetli ve aile terbiyesi almış bir kadındır. Adnan Bey'e âşık olan Matmazel, kibar, naif ve iyiliksever bir kadındır. Evlenmemiş ve çocuk sahibi bir anne olmamasına rağmen annelik içgüdülerini Nihal ile gidermiş, ona merhametle ve şefkatle yaklaşmıştır (Çetin, 2002; Bağc1, 2018: 106). Yalıdan ayrılıp Fransa'ya dönerken Nihal'in zarar görmemesi adına Behlül'den uzak durması ve dikkatli olması hususunda onu uyarmıştır. Toplumsal cinsiyet rolleri ve davranışlarıyla uyumlu olması sebebiyle olumlu, yapıcı yönleriyle kurgulanan Matmazel, anne şefkati, koruyuculuk, kadınsılık, duygusallık, merhamet ve sevgi duygularının temsili niteliğindedir.

Nihal, aynı ev içerisinde Behlül ile birlikte büyüyen ve ilk gördüğü erkekle (Behlül) evlenme teşebbüsünde bulunan, iffetli, terbiyeli ve temiz aşkın temsilidir. Nihal, duygusal, anne sevgisinden mahrum büyüyen ve iyi kalpli genç bir kadındır. Annesiz büyümüş, babası Adnan Bey de Bihter'le evlenince iyice yalnız kalmıştır. Behlül'e âşık olan Nihal, saf ve temiz aşkın, dürüstlüğün ve iffetli bir kadını temsili etmesi bakımından Bihter ve Firdevs Hanımın tersi bir karakterdir. Zengin ve lüks bir hayat sürmesine rağmen, ağır başlılığı, terbiyesi ve güzel ahlaklı oluşu ile Nihal, ideal bir eş, temiz kalpli bir kadını simgelemektedir.

\section{Anne Tipi, Merhametli ve Şefkatli Kadınlar: Matmazel De Courton}

Eserde çocuk sahibi olmamasına rağmen bir anne sevgisi ile Matmazel De Courton, ilgisini ve sevgisini Nihal'e yönlendirmiştir. Matmazel, koruyucu, merhametli ve iyiliksever bir kadın olarak belirmektedir. Onun bu sıfatları üstlenmesi, annelik statüsünün pekişmesini sağlamış, feminen, duygusal, koruyucu-kollayıcı, merhametli ve yardımsever bir kadın olarak algılanmıştır (Zariç, 2017: 153). Firdevs Hanım kızının Behlül ile ilişkisini fark ettiği anda kızının evliliğini koruyabilmek için bir annelik refleksi ile daha çok maddi kazanımları kaybetmemek adına Bihter'i Behlül 'den uzak tutmak için Nihal ile Behlül 'ün yakınlaşmasını sağlamıştır (Çetin, 2002: 35). Firdevs Hanımın bu tutumu daha çok, iktidar ve statüsünü kaybetmemek, sahip olduğu zenginliğin elinden gitmemesi için bir uğraş olarak değerlendirilebilir.

\section{Sonuç}

Halid Ziya Uşaklıgil'in değerli eseri Aşk-ı Memnu, kadınların toplumsal statü ve konumlarının toplumsal cinsiyet bakış açısıyla değerlendirilebilmesi için zengin bir

Turkish Academic Research Review - Türk Akademik Araştırmalar Dergisi 
veri kaynağı sunmaktadır. Aşk-ı Memnu'da yasak aşk konusu üzerine şekillenen mutsuz bir evlilik ve bu evliliğe yol açan sebepler ve sonuçları bireysel, psikolojik yönleriyle ele alınmaktadır (Kantemir, 1982; Kandiyoti, 1997). Eserde Batılılaşmayı, giyim, kuşam ve modadan ibaret gören, Fransızca öğrenmek, piyano çalmak ile modernleştiğini sanan insanların özgürlük aracıllğıyla Türk aile yapısına uygun düşmeyen yaşam biçimleriyle (gece partileri, gezintiler, flörtler ve yasak aşklar, kaçamak ilişkiler, aldatmalar, kamusal alanda erkek-kadın görünümleri) toplumsal ve kültürel değerleri kaybedişi anlatılmaktadır (Çetişli 2004; Tanpınar, 2007; Maden, 2008: 80,85).

Aşk-1 Memnu'da Tanzimat ve Servet-i Fünun dönemi edebiyatını kapsayacak iki türlü kadın tipi temsil edilmektedir. Birincisi, odalık, cariye, köle dahi olsa cinsel kimliğini saklamaya çalışan iffetli, edepli, uysal kadın tipi, diğeri ise maddi ve ten hazzından başka mutluluk bilmeyen entrikacı, iffetsiz ve ahlaksız kadın tipidir (Çetin, 2002: 20; Günay Erkol, 2011: 156). İlginç olan durum, iffetsizlik, arsızlı ve ahlaksızlık olarak adlandırılan davranış ve toplumsal eylem biçimlerinin modernleşme veya çağdaşlaşmanın bir simgesi olarak değerlendirilmesidir (Maden, 2008). Ayrıca hane içinde konumlandırılan kadınların saf, temiz, iffetli, fedakar ve erkeklere itaat eden ideal kadınlar olarak tanıtılması, kamusal alandaki kadınların düşkün, ahlaksız, iffetsiz nitelendirilmesi bir hayli çarpıcıdır (Şahin, 2015: 84). Eserde yer alan Firdevs Hanım, Matmazel, Nihal, Bihter, Peyker, Şayeste Hanım, Cemile gibi kadın karakterler genellikle birbirine zıt, ters yönde kişilikler olarak karakterize edilmiştir. Aldatan, entrikacı, iffetsiz kadınolarak kurgulanan Firdevs Hanım ve kızı Bihter'in yaşadıkları bireysel ve psikolojik çatışmalar abartılı bir şekilde anlatılırken erkek karakterlerin kadın karakterlere göre masum, saf, eğlenceli ve pozitif yönlerine vurgu yapılmıştır. Behlül'ün çok eşliliği, çapkınlığı, yaramaz ve sorumsuz tavırları olumsuz bir şekilde yansıtılmazken, namus, ahlak ve toplumsal değer çatışmaları kadın karakterler üzerinden sunulmuş olması dikkat çekicidir (Kaplan, 2002).Eserde her ne kadar Batı tipi bir yaşam süren bir yalı ve sakinlerinin bireysel yaşamlarından bahsedilmiş olsa da din kuralları ile yönetilen muhafazakâr bir toplumun varlığı söz konusudur (Günay Erkol, 2011: 160,161). Bu durum kamusal-özel alan, mekân ve sosyal ilişkilerin yönünü ve şeklini belirlemiştir. Behlül, görünüm, giyinme, sosyal pratikler olarak her ne kadar Batılı bir tip olarak sunulsa da düşünce, yaşam biçimi ve kültürel olarak ataerkil, statü ve iktidar eğilimli, çok eşli bir adamdır.İfettli olma, ağırbaşı olma, şefkat, sevgi duygularını belli eden Matmazel gibi kadınların davranışları doğru ve ideal bir biçimde sunulurken, evlilik konusunda seçme hakkı olan hatta bu konuda annesiyle 
tartışabilen Bihter'in sınırlı özgürlüğü eleştirilmektedir. Nitekim doğru ve ideal kadın tipinden kasıt; toplumsal cinsiyet rolleri ile uyumlu, sessiz, itaatkâr, fedakâr ve her bakımdan erkeğe bağlı bir kadın temsilidir. Toplumsal cinsiyet rolleri ile uyuşmayan kadınlar, maddi menfaat gözeterek mutsuz evlilik yapan, eşlerini kaybeden, maddi ve manevi hazza ulaşamayan, sonları hayırlı olmayan kadınlar olarak kurgulanması, eserin erkek egemen bakış açısıyla yazıldığını ortaya koymaktadır.

Bihter, Adnan Bey ile zenginliği ve parası için evlenmiş, toplumsal bir kurum olan aile kavramının gerektirdiği ahlaki olgunluktan uzak, anne olamayacak bir karakterdir. İhtirasları, kıskançlıkları, hane halkı ile olan ilişkileri açısından istenilmeyen bir kadın tipidir. Yasak aşkı ile eşi Adnan Beyin onuruna leke getirmiş, namusunu ve eşinin onurunu korumak için kendini kurban ederek intihar etmiştir. Bihter'in canına kıymasının arkasında yatan sebep erkek egemenliğine karşı direnememesi, özgürlüğ̈̈n ve ahlaki sınırlılığın varlığıdır. Bihter, intihar ederken Behlül 'ün veya Adnan Bey'in bu olayda sorumluluğundan bahsedilmemesi, Behlül'ün Hollandalı tiyatro oyuncusu Kette ile birlikteliği, çapkınlığı, çok eşliliğinin vurgulanmaması ataerkilliğin izdüşümü olarak algılanabilir. Eserde zenginlik, iktidar ve statünün erkek karakterlerde olması, kadınların bu zenginlikten faydalanmak için erkeklere yaranmaya, yakınlaşmaya çalışması toplumsal cinsiyet normlarının yansıması olarak değerlendirilebilir (Bağcı, 2018: 107).

\section{Kaynakça}

Ahmet Mithat Efendi (2020). Felatun Bey İle Rakım Efendi, İstanbul: Salon Yayınları.

Atay, T. (2004). Erkeklik En Çok Erkeği Ezer, Toplum Ve Bilim, Güz.

Bağcı, Y. Y. (2018). Aşk-I Memnu'da Erkeğin Sunumu. Akdeniz Üniversitesi Sosyal Bilimler Enstitüsü Dergisi, (4), 97-108.

Berktay, F. (2000). Tek Tanrılı Dinler Karşısında Kadın, İstanbul: Metis Yayınları.

Connel, R. W. (2001). Studying Man And Masculinity, Resourcesfor Feminist Research, Fall-Winter.

Çetişli, İ. (2004). Metin Tahlillerine Giriş (Roman- Hikâye-Tiyatro) 2, Ankara: Akçağ Yayınları.

Turkish Academic Research Review - Türk Akademik Araştırmalar Dergisi https://dergipark.org.tr/tr/pub/tarr 
Çetin, N. (2002). II. Abdülhamit Dönemi Türk Romanında “Aşk-1 Memnu” Teması, Türkoloji Dergisi, 15(1), 19-59.

Demir, E. (2018). Kadınların Siyasal Katılımı Antalya'da AK Parti Ve CHP Kadın Kolları Örneği, Yayımlanmamış Yüksek Lisans Tezi, Akdeniz Üniversitesi Sosyal Bilimler Enstitüsü, Antalya.

Demir, E. (2020). Toplumsal Cinsiyet Bağlamında Kadının Siyasetteki Rolü Ve Önemi, Yunus Emre Tansü (Ed.), Abay Kunanbayev Anısına Türkiye Ve Türk Dünyası Araştırmaları-III, İKSAD Publishing House, Gaziantep,833-863.

Ecevit, Y. (2011). Toplumsal Cinsiyet Sosyolojisine Başlangıç, Yıldız Ecevit Ve Nadide Karkıner (Ed.). Toplumsal Cinsiyet Sosyolojisi, Eskişehir: Anadolu Üniversitesi Yayını, 2-29.

Elçik, G. (2011). Cinsellik Ve Beden, Toplumsal Cinsiyet Çalı̧̧maları, Yıldız Ecevit Ve Nadide Karkıner (Ed.). Eskişehir: Anadolu Üniversitesi Açıöğretim Fakültesiyayınları,140-167.

Gökçek, F. (2000). Tanzimat Dönemi Roman Ve Hikâyelerinde Kadın Erkek İlişkilerinin Düzenlenişi İle İlgili Bazı Tespitler, Türk Yurdu, 126-132.

Gülendam, R. (2006). Türk Romanında Kadın Kimliği (1946-1960), Erzurum: Salkımsöğ̈̈t Yayınları.

Günay-Erkol, Ç. (2011). Osmanl1-Türk Romanından Çağdaş Türk Romanına Kadınlık: Değişim Ve Dönüşüm, Türkiyat Mecmuası, 21(2), 147-175.

Kandiyoti, D. (1997). Cariyeler, Fettan Kadınlar Ve Yoldaşlar: Türk Romanında Kadın İmgeleri; Cariyeler, Bacılar, Yurttaşlar: Kimlikler Vetoplumsal Dönüşümler, İstanbul: Metis Yayınları.

Kantemir, E. (1982). Aşk-I Memnu Eser İncelemesi, Eğitim Bilimleri Fakültesi Dergisi, 15(1), 227-239.

Kaplan, R. (2002). Aşk-I Memnu: Evinde Bir Yabancı Adam, Hece Roman Özel Saylsı. 65/65/67, 550-559.

Karabulut, M. (2013). Tanzimat Dönemi Türk Romanında Kadın Üzerine Tematik Bir İnceleme, Erdem Dergisi, 49-69.

Karkıner, N. (2011). Aile Ve Evlilik, Yıldız Ecevit Ve Nadide Karkıner (Ed.). Toplumsal Cinsiyet Sosyolojisi, Eskişehir: Anadolu Üniversitesi Yayını, 130-154.

Maden, S. (2008). Aşk-I Memnû Ve Madam Bovary Romanlarında Kadınların Yönlendirdiği Olay Örgüsü. Türklük Bilimi Araştırmaları, (24), 79-97. 
Moran, B. (1999). Türk Romanına Eleştirel Bakış 1, İstanbul: İletişim Yayınları.

Namlı, T. (2019). Tanzimat Romanında Alafranga Züppe Eleştirisi, Adlyaman Üniversitesi Sosyal Bilimler Enstitüsü Dergisi, Sayı 11, 189-239.

Nisan, F. \& Bekiroğlu Akçay, H. (2016). Aşk-I Memnu Dizisinin Alımlanması Üzerine Bir Çalışma, Karadeniz Teknik Üniversitesi, İletişim Fakültesi Elektronik Dergisi, 3(12), 47-66.

Öztürk, R. (1998). An Assessment Of Charles Dickens's Great Expectationsand Halit Ziya Uşaklıgil’n Aşk-I Memnu, Balıkesir Üniversitesi Sosyal Bilimler Enstitüsü Dergisi,1(2),122-136.

Tanpınar, A. H. (2001). Huzur, İstanbul: Yapı Kredi Yayınları.

Tanpınar, A. H. (2007). 19. Asır Türk Edebiyatı, İstanbul: Çağlayan Kitabevi.

Tekin, S. (2010). Osmanlı'da Kadın Ve Kadın Hapishaneleri, Tarih Araştırmaları Dergisi, 29(47), 83-102.

Sancar, S. (2011). Erkeklik, Yıldız Ecevit Ve Nadide Karkıner (Ed.). Toplumsal Cinsiyet Çalışmaları, Eskişehir: Anadolu Üniversitesi Yayınları, 168-191.

Şahin, S. (2010). Romandan Tiyatroya Aşk-I Memnu, Folklor/Edebiyat Dergisi, 16(64), 121-130.

Şahin, E. (2015). Fall Of Women İn British Literatureandturkishliterature Of 19th Century: A Comparativeapproach, The Journal Of Academic Social Science Studies, Pp 83-97.

Uşaklıgil, H.Z. (2008).Aşk-I Memnu, İstanbul: Özgür Yayınları

Zariç, M. (2017). Aşk-I Memnu'da Karakterlerin Çatışmaları, Tercihleri Ve Akıbetleri, Uluslararası Sosyal Araştırmalar Dergisi, 10 (50), 150-157.

Turkish Academic Research Review - Türk Akademik Araştırmalar Dergisi https://dergipark.org.tr/tr/pub/tarr 